Тодуров I.М., Купець В.С., Прохоренко О.К., Панасенко О.О., Перехрестенко O.В., Косюхно С.В., Плигуца О.І., Бака O.М.

\title{
Прикрита перфорація дивертикулу сигмоподібної кишки. Мультидисциплінарний підхід до діагностики та лікування (клінічний випадок)
}

Державна наукова установа «Центр інноваційних медичних технологій НАН України», м. Київ, Україна

todurov@nas.gov.ua,perekhrestenko@nas.gov.ua

Тодуров И.М., Купец В.Е.,

Прохоренко О.К., Панасенко А.А., Перехрестенко А.В., Косюхно С.В., Плигуца А.И., Бака Е.М.

Прикрытая перфорация дивертикула сигмовидной кишки. Мультидисциплинарний подход

к диагностике и лечению (клинический случай)

Государственное научное учреждение

«Центр инновационных медицинских технологий НАН Украины», г. Киев, Украина
Todurov I.M., Kupets V.E.,

Prokhorenko O.K., Panasenko O.O., Perekhrestenko A.V., Kosyukhno S.V., Pligutsa A.I., Baka O.M.

Covert perforation of the sigmoid colon diverticulum.

A multidisciplinary approach to diagnosis and treatment (clinical case)

State Scientific Institution "Center for Innovative Medical

Technologies of the NAS of Ukraine", Kyiv, Ukraine

\section{Актуальність питання}

У 86-90\% випадків дивертикули товстої кишки

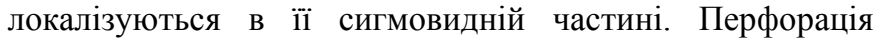
дивертикулу $\epsilon$ найбільш тяжким ускладненням i за різними даними, спостерігається від 1 до 27,2\% [1,2].

У більшості випадків, причиною перфорації $\epsilon$ гнійна деструкція або пролежень стінки дивертикулу на тлі попередніх запальних явищ. У переважній більшості випадків, перфоруються набуті (псевдодивертикули) дивертикули, в стінці яких відсутній м'язовий шар, а слизова оболонка кишки випинається в проміжках між м'язами.

Слабкість стінки дивертикулів, вузька шийка, викликають в них застій кишкового вмісту, часто 3 утворенням калового каменю, що в свою чергу, призводить до запальних змін - гострих і хронічних - атрофії, мацерації, некрозу стінки дивертикулу, а в кінцевому підсумку до перфорації і виникненню важких ускладнень, що вимагає трудомісткого, дорогого і тривалого лікування та нерідко призводить до інвалідності $[3,4]$.

Залежно від локалізації перфорації:

- в навколокишкову клітковину, брижу або вільну черевну порожнину спостерігаються різні клінічні прояви 3 наступних причин:

- невеликої кількості кишкового вмісту, що потрапляє в черевну порожнину;

- більш слабкої подразнюючої дії калової маси на очеревину від дії вмісту вищерозташованих відділів шлунково-кишкового тракту;

- низька реактивність організму, пов'язана з похилим віком більшості пацієнтів;
- проявами супутніх захворювань.

У зв'язку 3 цим, діагностика перфоруючих дивертикулів на даний час $є$ серйозної проблемою, тому в таких випадках, важливе значення мають загальноклінічні прояви такі як підвищена температура тіла, лейкоцитоз, біль в животі та симптоми подразнення очеревини та інструментальні методи дослідження, такі як рентгендослідження грудної клітини та черевної порожнини, КТ органів черевної порожнини, іриго- і колоноскопія [5-6].

Диференційна діагностика проводиться 3 кишковими коліками, перфорацією виразки шлунку та 12-ти палої кишки, запальними хворобами кишківника або сечо-статевої системи [7-10].

Таким чином, повноцінне, своєчасне i якісне проведення комплексного обстеження хворого 3 цією патологією забезпечує найкращий результат і динаміку в лікуванні в найкоротші терміни.

\section{Матеріали та методи}

Дослідження проведено на підставі мультидисциплінарного обстеження i оперативного лікування пацієнта.

\section{Результати дослідження та їх обговорення}

Розгляду підлягає конкретний клінічний випадок.

До гастроентерологічного відділення Державної наукової установи «Центр інноваційних медичних технологій НАН України» (далі Центр) 08.01.2020 p надійшла пацієнтка I., у віці 63 років, зі скаргами на болі в епігастральній ділянці живота, метеоризм і закрепи. 
При клініко-інструментальному і лабораторному обстеженні результати загального і біохімічного аналізу крові, в межах вікової норми.

При проведенні відеоезофагогастродуоденоскопічного дослідження виявлено: хронічна еритематозна гастродуоденопатія, поодинокі ерозії шлунку.

В результаті проведення відеоколоноскопії виявлено гігантський дивертикул в нижній третині сигмоподібної кишки 3 явищами дивертикуліта. Слизова гирла інфільтрована, гіперемована, набрякла. Слизова купола дивертикулу витончена (див. малюнок 1).

У зв’язку з високим ризиком перфорації тотальна колоноскопія не виконувалася.

Унаслідок посилення болів в області живота, пацієнтка переведена в хірургічне відділення Центру. За час спостереження виконана рентгенографія органів черевної порожнини, в результаті якої виявлено вільний газ під обома куполами діафрагми (див. малюнок 2).

За результатами інструментальних, фізикальних обстежень та динамічного спостереження, хворій встановлено діагноз: Дивертикул, дивертикуліт сигмоподібної кишки. Перфорація дивертикулу сигмоподібної кишки?
За життєвими показаннями, під загальною анестезією виконана діагностична лапароскопія. У черевній порожнині визначається вільний газ та в зоні нижньої третини сигмоподібної кишки виявлено дивертикул до 2 см в діаметрі, 3 широкою основою. Стінки його різко витончені, представлені серозною оболонкою кишки. Дивертикул оточений жировими підвісками з частковою імбібіцією газу, без явного перфоративного отвору (див. малюнок 3).

Виконано лапароскопічну резекцію дивертикулу 3 ушиванням дефекту дворядним швом типу PDS 3-0.

Післяопераційний період - без особливостей. У задовільному стані пацієнтка виписана на 7-му добу. Повторні огляди та обстеження пацієнтки свідчать про позитивну динаміку і успішний результат.

\section{Висновки}

При всій складності діагностика і лікування прикритої перфорації дивертикулу товстої кишки, мультидисциплінарна взаємодія лікарів-фахівців відіграє вирішальну роль для правильної тактики ведення пацієнтів з даною патологією.

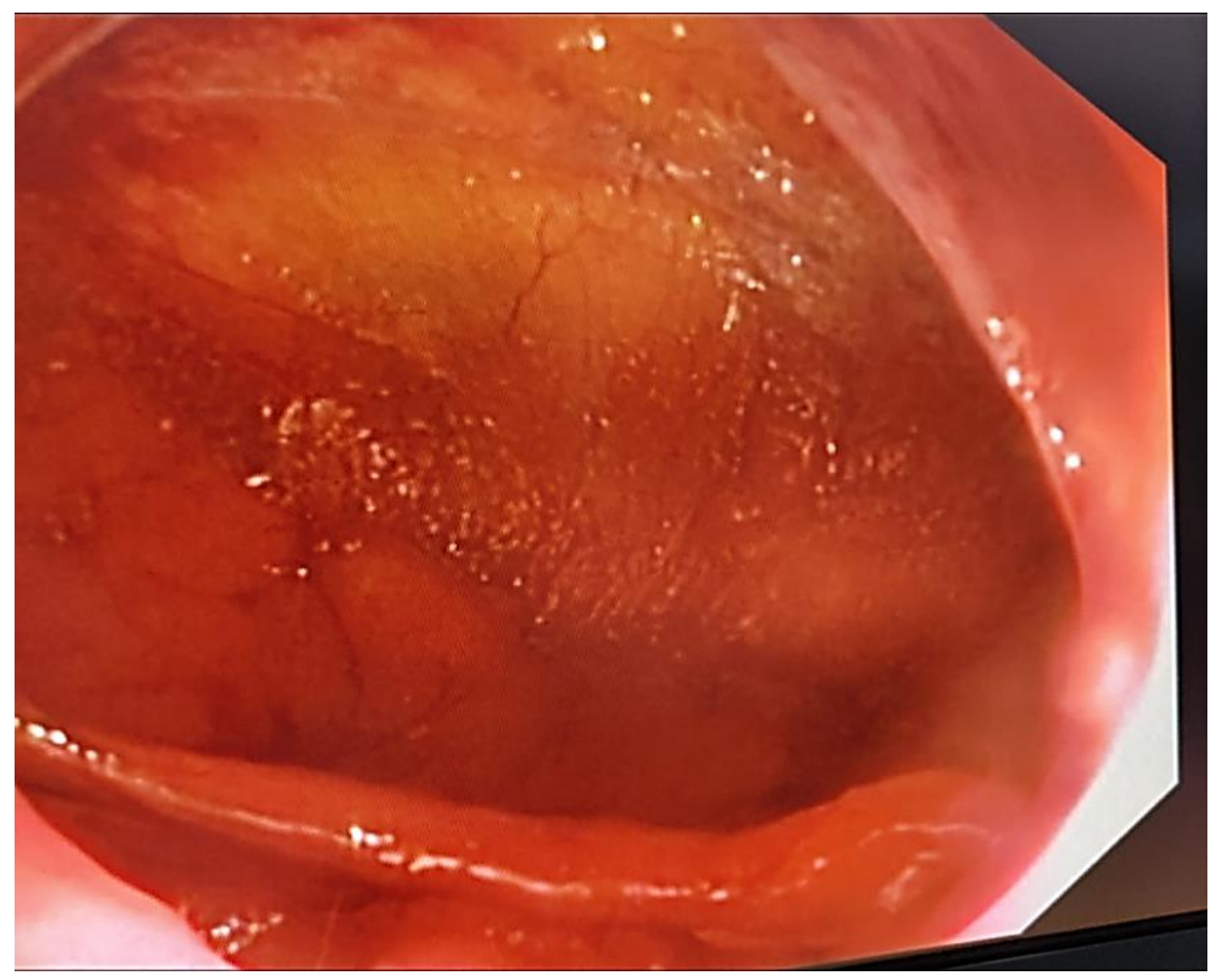

Мал. 1. Відеозображення дивертикулу сигмоподібної кишки (Тодуров І.М. з співавт.)

Опис: купол дивертикулу представлений витонченою серозною оболонкою, прямої перфорації немає. 
Kkpitha

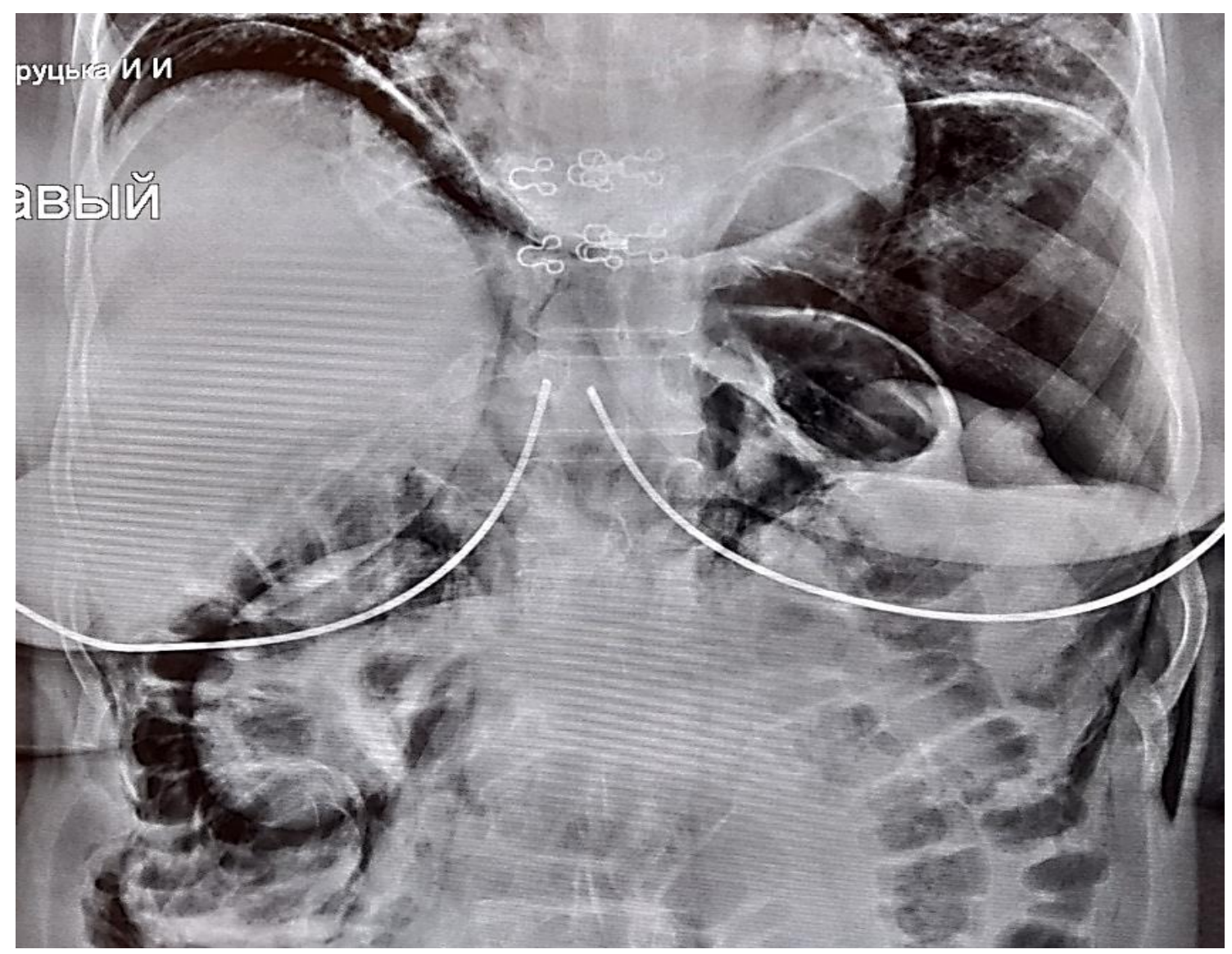

Мал. 2. Рентгенографія органів черевної порожнини (Тодуров І.М. з співавт.) Опис: Виявлено вільний газ під обома куполами діафрагми.

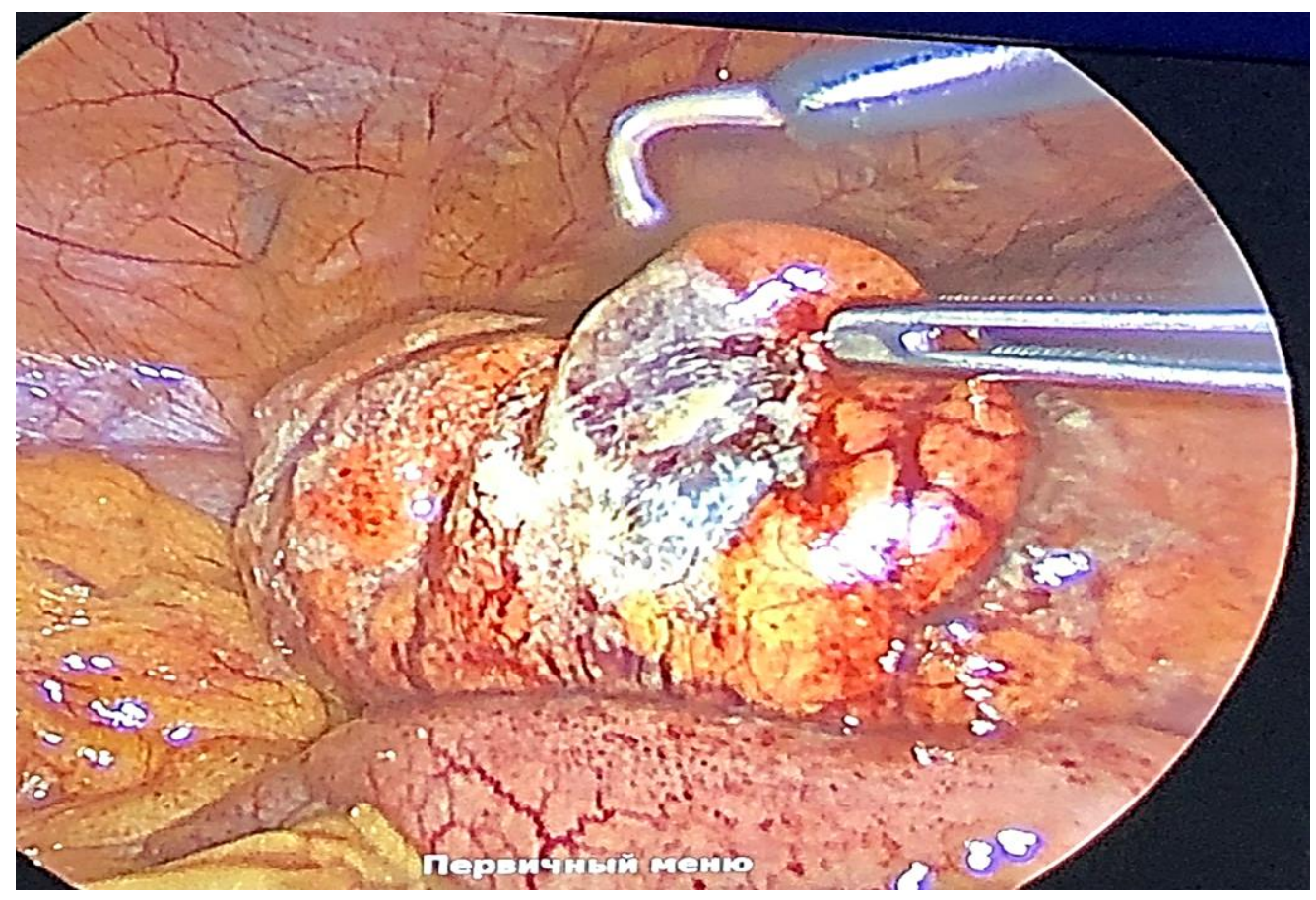

Мал. 3. Відеолапароскопічне зображення дивертикулу сигмоподібної кишки (Тодуров І.М. з співавт.) Опис: Дивертикул сигмоподібної кишки (до 2-х см розміром). Стінки його різко витончені, представлені серозною оболонкою. Явного перфоративного отвору не виявлено. 


\section{Література}

1. Вестник хирургии им. И.И.Грекова, 2003, №2, с. 94-96. Авторы: Борисов А.Е., Кубачев К.Г., Малкова С.К.

2. Jensen DM, Machiado GA, Jutabha R, et al. Urgent Colonoscopy for the Diagnosis and Treatment of Severe Diverticular Hemorrhage. N Engl J Med, 2000; 342: 78-82 p.

3. Свтушенко О.І., М'ясоєдов Д.В., Шевелюк С.Б. Ендоскопія товстої кишки: Навчальний посібник. К.: Вістка, 2007. - 292 с.

4. Ан В.К. Неотложная проктология. М. Медпрактик 2003. 144 с.

5. Iqbal CW, Chun YS, Farley DR. Colonoscopic perforations: a retrospective review. J Gastrointest. Surg. 2005 Dec.; 1229- $36 \mathrm{p}$.

6. Hall C., Dorricott, N.J., Donovan, I.A., et al., 2005. Colon perforation during colonoscopy: surgical versus conservative management. Br. J. Surg. 78 (5), 542-544 p.

7. Руководство по клинической эндоскопии. Авт: В.С. Савельев, Ю.Ф. Исаков, Н.А. Лопаткин, и др. М. Медицина, 1985, 544 с.

8. Шалимов А.А,, Саенко В.Ф. Хирургия пищеварительного тракта. К: Здоров'я. 1987. - 568 с.

9. Differential diagnosis of colorectal diseases. Kou Nagasako. Igaku-Shoin LTD, Tokyo, 1982, 315 p.

10. Gastroenterologic Endoscopy. Michael V Sivak, Jr. W.B. Saunders Company, 1987, 1168 p.

Дата надходження рукопису до редакції: 29.05.2020 p.

Мета: обгрунтувати доцільність мультидисциплінарного підходу до діагностики та лікування хворих 3 прикритою перфорацією дивертикулу сигмоподібної кишки для поліпшення результатів обстеження і лікування даної патології.

Матеріали та методи. Проведено аналіз доцільності мультидисциплінарного підходу до діагностики та лікування прикритої перфорації дивертикулу сигмоподібної кишки.

Результати. Мультидисциплінарний підхід до діагностики та лікування хворих з прикритою перфорацією дивертикулу сигмоподібної кишки суттєво покращує показники своєчасної та якісної діагностики та результати лікування хворого, що є вирішальним фактором при даній патології в досягненні позитивного результату.

Висновки. При всій складності діагностика і лікування перфорації дивертикулу товстої кишки, мультидисциплінарний підхід і взаємодія лікарів-фахівців грає вирішальну роль для правильної тактики ведення пацієнтів 3 даною патологією.

Ключові слова: прикрита перфорація дивертикулу сигмоподібної кишки, мультидисциплінарний підхід до діагностики та лікування.

Цель: обосновать целесообразность мультидисциплинарного подхода к диагностике и лечению больных с прикрытой перфорацией дивертикула сигмовидной кишки с целью улучшения результатов обследования и лечения данной патологии.

Материалы и методы. Проведен анализ целесобразности мультидисциплинарного подхода к диагностике и лечению прикрытой перфорации дивертикула сигмовидной кишки.

Результаты. Мультидисциплинарный подход к диагностике и лечению больных с прикрытой перфорацией дивертикула сигмовидной кишки существенно улучшает показатели своевременной и качественной диагностики и результаты лечения больного, что является решающим фактором при данной патологии.

Выводы. При всей сложности дагностики и лечения перфорации дивертикула толстой кишки, мультидисциплинарное взаимодействие врачей-специалистов оказывает решающую роль для правильной тактики ведения пациентов с данной патологией.

Ключевые слова: прикрытая перфорация дивертикула сигмовидной кишки, мультидисциплинарний подход к диагностике и лечению.

Purpose: to justify the feasibility of a multidisciplinary approach to the diagnosis and treatment of patients with covered perforation of the sigmoid colon diverticulum in order to improve the results of examination and treatment of this pathology.

Materials and methods. The feasibility analysis of a multidisciplinary approach to the diagnosis and treatment of ruptured perforation of the sigmoid colon diverticulum was carried out.

Results. A multidisciplinary approach to the diagnosis and treatment of patients with covered perforation of the sigmoid colon diverticulum significantly improves the indicators of timely and high-quality diagnosis and treatment results of the patient, which is a decisive factor in this pathology.

Conclusions. Despite the complexity of the diagnosis and treatment of perforation of the diverticulum of the colon, the multidisciplinary interaction of medical specialists has a decisive role for the correct tactics of managing patients with this pathology.

Key words: covert perforation of the sigmoid colon diverticulum, multidisciplinary approach to diagnosis and treatment. 
Конфлікт інтересів: відсутній.

Conflicts of interest: authors have no conflicts of interest to declare.

\section{Відомості про авторів}

Тодуров Іван Михайлович - Лауреат державної премії в галузі науки і техніки, Заслужений лікар України, доктор медичних наук, професор; директор (тут і далі) ДНУ «Центр інноваційних медичних технологій НАН України»; 04053, м. Київ, Вознесенський узвіз, 22.

todurov@nas.gov.ua.

Купець Валерій Євгенович - лікар-ендоскопіст, відділення ендскопії.

Прохоренко Ольга Кімівна - лікар-ендоскопіст, відділення ендскопії.

Панасенко Олександр Олексійович - лікар-ендоскопіст, відділення ендскопії.

Перехрестенко Олександр Васильович - Заслужений лікар України, доктор медичних наук, ст.н.с.; заступник директора з наукової роботи.

perekhrestenko@nas.gov.ua.

Косюхно Сергій Вікторович - кандидат медичних наук, завідувач відділу малоінвазивної хірургії.

Плигуца Олександр Іларійович - кандидат медичних наук, заступник головного лікаря з хірургічної роботи.

Бака Олена Михайлівна - завідуюча гастроентерологічним відділенням.

Примітка. У статтях збережено орфографію, пунктуацію та стилістику авторів. 